\title{
Community Evaluation and Impact Assessment of Revitalization Project: A Case Study in Hong Kong
}

\author{
Binqing Zhai ${ }^{*}$, Albert P. C. Chan ${ }^{2}$ \\ ${ }^{1}$ Department of Architecture, Xi'an Jiaotong University, Xi'an, China \\ ${ }^{2}$ Department of Building and Real Estate, The Hong Kong Polytechnic University, Hong Kong, China \\ Email: *bqzhai@mail.xjtu.edu.cn
}

How to cite this paper: Zhai, B.Q. and Chan, A.P.C. (2018) Community Evaluation and Impact Assessment of Revitalization Project: A Case Study in Hong Kong. Journal of Building Construction and Planning Research, 6, 23-40. https://doi.org/10.4236/jbcpr.2018.62002

Received: March 24, 2018

Accepted: May 28, 2018

Published: May 31, 2018

Copyright $\odot 2018$ by authors and Scientific Research Publishing Inc. This work is licensed under the Creative Commons Attribution International License (CC BY 4.0).

http://creativecommons.org/licenses/by/4.0/

\section{cc) (i) Open Access}

\begin{abstract}
With the aim of promoting sustainable conservation and development of historic buildings in Hong Kong, the Hong Kong government introduced the Revitalizing Historic Buildings Through Partnership Scheme in 2007 to conserve and revitalize government-owned historic buildings. Since the announcement of the Revitalization Scheme, many people have criticized that the revitalization projects ended up not for the benefit of the local communities. Based on a completed revitalization project (the former North Kowloon Magistracy building) and situated within the literature of revitalization practices, community involvement, community evaluation, and impact assessment, this paper explored how community involvement with the revitalization project might influence the community's evaluation of the project's outcomes. The research found that community connections or involvement with the revitalization project significantly affected the community's evaluation of the project's various impacts.
\end{abstract}

\section{Keywords}

Community Involvement, Community Evaluation, Impact Assessment, Revitalization Project, Hong Kong

\section{Introduction}

In the current literature on revitalizing obsolescent historic buildings, strategic development plans largely emphasize the conservation and adaptive reuse of original buildings [1] [2]. Empirical studies revealed that when historic buildings possessed no further utilizations, the buildings were often associated with deteriorated economic situations, which would subsequently speed up the decay of 
these buildings [3]. With regard to the relationship between a building's physical and economic conditions, Harvey eloquently stated that "[economic] capital builds a physical landscape appropriate to its own conditions at a particular moment in time [4]." Accordingly, many studies highlighted that successful revitalization of historic buildings should seek a satisfactory balance between conservation and adaptive reuse of the original built forms, and the strategy of adaptive reuse was closely related to the economic development of the revitalization projects [1] [5]. After all, historic buildings needed sustained economic investment to refurbish and maintain the buildings [6]. UNESCO also indicated that juxtaposing the multi-objectives (i.e., conservation, adaptive reuse, and economic development) constituted the critical factors to attract commercial investment and facilitate local sustainable development [3]. Therefore, finding new uses associated with active economic activities for the conserved historic buildings was considered essential to successfully achieve revitalization objectives [2].

In the context of an Asian global city, such as Hong Kong, where economic development has always taken the predominant position in its urban development strategy, heritage has long been criticized as largely neglected. In October 2007, the Hong Kong Special Administrative Region (SAR) government proactively responded to the criticism by introducing the Revitalizing Historic Buildings Through Partnership Scheme to conserve and revitalize local government-owned historic buildings [7]. Under this scheme, the government would pay all initial costs related to the building renovations for subsequent leasing to service providers of social enterprises without expecting them to shoulder these costs. In return, the service providers operated the social enterprises with their own funds [8]. When the application results of the service providers of the revitalization projects in 2009 were announced, numerous debates occurred over the effect of these projects on Hong Kong society. Many people criticized that the proposed Revitalization Scheme ended up not for the benefit of local communities [9]. These contentions are closely related to community evaluations of the revitalization projects' outcomes.

Literature revealed a connection between community satisfaction or favorable evaluation of development projects and community involvement with the projects. Most studies related why community participation was important for high levels of evaluations [10] [11] and how to achieve multi-dimensional urban development objectives through community participation [12] [13]. Comparatively, the issue of community participation in urban development in Hong Kong is unique and different. Hong Kong has often been criticized as an undemocratic executive government-led city, and the situation of community participation in urban development has undergone tremendous changes since the handover of Hong Kong's sovereignty to China after 1997 [14]. Given the context that economic development plays a dominant role in the urban development plans of the Hong Kong government, this study interlinked several key issues, including the revitalization project, community involvement, community 
evaluation, and impact assessment, to explore how community involvement with the revitalization project influenced the community evaluation of the project's outcomes. On the basis of a completed revitalization project, the former North Kowloon Magistracy (NKM) building, this study explored the following questions: Did the conservation and revitalization practices contradict the local economic development objectives? What factors significantly affected the local community's evaluations of the revitalization project in Hong Kong? How did community involvement influence the levels of community evaluation of the project?

\section{Background: Revitalization Scheme, Perceptual Impacts, and Community Participation in Hong Kong}

\subsection{Revitalization Scheme and Its Perceptual Impacts}

The initiative of Revitalizing Historic Buildings Through Partnership Scheme (hereafter referred to as the Revitalization Scheme) in Hong Kong was first proclaimed in the Hong Kong government's 2007-2008 Policy Address, which proposed both conservation and adaptive reuse of government-owned historic buildings in Hong Kong to maximize the economic and socio-cultural benefits of historic buildings [15]. An outstanding feature of the Revitalization Scheme was that it did not entirely rely on the investment from the government or private sectors. In contrast with traditional public-private partnership (PPP) projects, which were fully or partially financed by private parties, the Revitalization Scheme proposed to finance all the initial costs of the project covering the renovation of historic buildings. The renovated buildings would then be rented to selected service providers, the non-profit-making non-governmental organizations (NPOs) in the form of social enterprises. Local academics referred to this type of collaborated development model as a social PPP mode [16]. Notably, such financial assistance from the Hong Kong government would only last for the initial two years, and the service providers would need to operate the social enterprises using their own funds afterward [17].

Since the implementation of the Revitalization Scheme, the Hong Kong society has expressed various concerns about the selection of service providers, especially on the case of the former North Kowloon Magistracy (NKM) building. Two biggest bidders for the service providers of the revitalization project included a local institution for Cantonese opera, the Chinese Artists Association (CAA), and an American art college, the Savannah College of Art and Design (SCAD). Critics argued that if the former NKM building could serve as the new theatre for the local Cantonese opera, it would contribute to the protection of local opera culture and promote the involvement of the local community in opera activities. The Hong Kong government was suggested to prioritize the local organization (i.e., CAA) because providing more job opportunities to the Hong Kong community was also one of the objectives of the Revitalization Scheme. Despite this strong suggestion, SCAD eventually won the bid as the service provider of the NKM project [9]. According to the Advisory Committee on Revita- 
lization of Historic Buildings (ACRHB), the proposal by the CAA was not convincing in terms of its financial capability to run the social enterprise by itself in the future.

\subsection{Community Participation and Community Satisfaction}

Arnstein defined participation as a channel for "the redistribution of power that enables the have-not citizens ... to be deliberately included in the future" [18]. The World Bank defined participation as "an active process whereby beneficiaries influence the direction and execution of development projects rather than merely receive a share of project benefits" [19]. In the first definition, the redistribution of power to the have-not community members was highlighted, which was critically important for community members to effectively participate in urban development. The second definition emphasized the influence of community involvement on the process of urban development projects rather than on the mere outcome. For the purposes of this research, community participation in the revitalization of historic buildings followed the definition by the World Bank. In this research, community participation was defined as an active process, whereby the identified community members or stakeholders influence the decision making, direction, and implementation of revitalization projects as well as the benefit of the projects' outcome in terms of enhancing the overall well-being of the community.

Literature revealed a connection between community satisfaction or favorable evaluation of development projects and community involvement with the projects. From a political perspective, people tended to challenge the paternalistic nature of development plans and initiatives led by the government. Empirical studies demonstrated that people were less interested in the "expert-controlled approach" to development projects because this type of approach tended to prioritize the development aims, which frequently did not benefit the concerned communities [3]. Reid claimed that when community members were involved in development projects, they would likely have the control of the local governing board and the "empowerment" approach, which was associated with the provision of necessary resources to achieve the local community's expected aims [11]. Therefore, through community participation, community members could express and pursue individual interests as well as the rights and duties of collective well-being [10]. In this manner, community participation enhanced the connections between the community and development projects and facilitated the community to benefit directly or indirectly from the projects. Thus, community participation would potentially increase the community's satisfaction toward the projects [20] [21]. With the local community's involvement in development projects, a mutual understanding was believed to develop between the community and the decision making on the projects, and the community tended to be more satisfied toward the adopted development strategies [3]. In addition, the authorities or decision makers of urban development projects are often con- 
fronted with many difficulties and problems, whose proper answers often depend on the involvement of local knowledge [12] [13] [22].

\subsection{Community Participation in Hong Kong}

Generally, Hong Kong is characterized by a top-down and executive-led government jurisdiction in urban planning and development projects. As an undemocratic executive government-led city, the situation of public participation in Hong Kong's urban development has long been criticized by many people. When Hong Kong was a British-colonized city, public participation in urban development had been considered insignificant [14]. In a "borrowed place, borrowed time," many Hong Kong people did not have a strong sense of belonging and would be satisfied with being able to make a living while the colonial government maintained the law and order [23]. Academics pointed out that, as a British colony, communication was limited between the ruling and ruled classes in the Hong Kong society. Without democracy, many Hong Kong people even waived their rights as "social beings" [24]. In this regard, public participation could hardly become a serious concern in the daily lives of Hong Kong people.

The situation has largely changed since the handover of Hong Kong's sovereignty to China after 1997, and many Hong Kong people have begun to actively seek their rights to participate in city development and heritage conservation matters [14]. Governmental institutions concerned with public participation within and outside of the government system have been set up within the framework of promoting sustainable development of Hong Kong. Since 2001, the Sustainable Development (SD) Unit was established under the administration of the Chief Secretary for Administration, which is now a division of the Environment Bureau. The major function of the SD Unit is to manage and administer the sustainability assessment of government projects and proposals. At the same time, a professional council, the Council for SD, was established by the Chief Executive in 2003. The council was outside of the government body and had the initiative to provide expert advices on sustainable development strategies to the Hong Kong administrative government. As a statutory body, the Council for $\mathrm{SD}$ is also responsible for regularly informing the public about urban development issues to promote sustainability in Hong Kong. Despite the objectives of establishing the Council for SD, Cheng criticized that the council had been mainly involved with "steering public education through publicity programmes" [25]. With ineffective governmental institutions, public participation in development projects in Hong Kong can only be classified as "consultation" and "informing" at the tokenism stage against Arnstein's participation ladder [18].

\section{Case Study of the Former North Kowloon Magistracy Building}

The revitalization of the former NKM building was selected as the case study in this research. Among the batch I of the revitalization projects proposed by the 
Hong Kong government since 2009, the former NKM building was the first to start and be completed. Currently, the NKM building serves as the Hong Kong branch campus of the Savannah College of Art and Design (SCAD HK). SCAD HK was officially opened in October 2011. The NKM project was extensively explored to examine the relationships between the local community's involvement with the project and the community's evaluations of the project's multi-perspective impacts, particularly the social, cultural, and economical impacts.

Located in Sham Shui Po District, Kowloon, the NKM building was constructed in 1960. It served the north Kowloon district community as a magistracy building from 1960 to 2005. The building was closed down in 2005 as part of the local government's cost-saving policy to reduce the number of magistracies in Hong Kong [26]. The building had four magistrates courts as well as one juvenile court on the lower levels and government offices on the upper levels. In Hong Kong's history, a magistrates court handled minor offenses, such as prostitution, littering, and traffic [16]. Architecturally, the NKM building was a representative example of civic buildings of that period (Figure 1).

\subsection{Data Collection}

The research used impact assessment indicators to examine the situation of Hong Kong community's evaluation of the concerned revitalization project. To derive the corresponding indicators, the method of social impact assessment (SIA) was adopted, which was used to assess the social consequences that were likely to result from development projects [27]. Mathur claimed that SIA was a tool that could help decision makers in foreseeing the likely negative impacts of their actions such that necessary measures could be undertaken in time to prevent these impacts [28]. The primary purpose of SIA is to create a more sustainable and equitable human environment. According to Vanclay, ideal SIA indicators should trigger the impacts across other domains when changes in one domain occurred [29]. Good SIA practice should accept that multi-perspective impacts are inherently and inextricably interconnected.

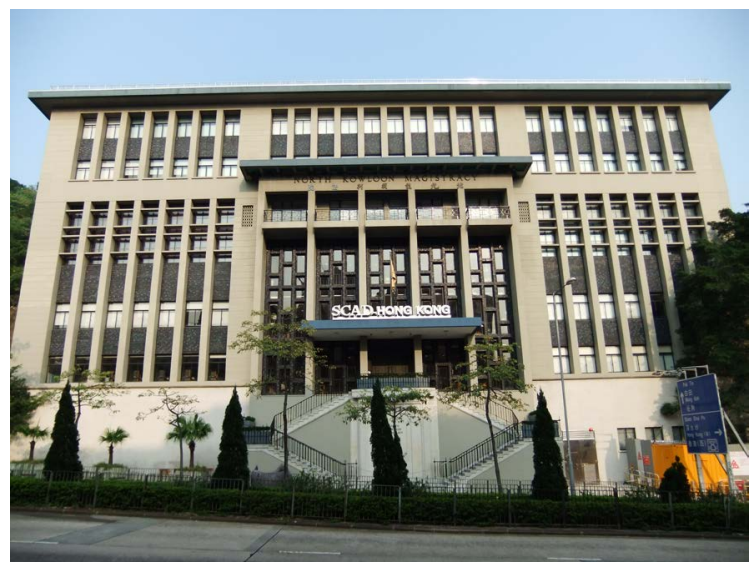

Figure 1. Front view of NKM building (SCAD HK) after renovation. 
The impact assessment in this research was defined as the efforts to assess the consequences or impacts on various domains that were likely caused by the revitalization project. The impact assessment indicators concerned the social, cultural, and economic impacts of the revitalization projects on the Hong Kong community. The indicators should point to the measurable changes concerning the local community change, social relations, historically built environments, and economic conditions. After researching on these issues through extensive literature review [5] [6] [15] [28] [29] [30] [31], the present study generated a list of impact assessment indicators, and on the basis of the list, a set of questions were further developed (Table 1).

By implementing impact assessment, the key affected stakeholders in the NKM case were first identified. In this research, community members or stakeholders in the revitalization projects were defined as "those who can influence the project process and/or final results, whose living environments are positively or negatively affected by the project, and who receive associated direct and indirect benefits and/or losses" [32]. Based on field survey and face-to-face interviews with the local community, the key stakeholders in this research mainly included the project contractor workers, project end-users (SCAD HK), local residents, and the public or the concerned group. The connections between the identified key stakeholders and the NKM project are indicated in Table 2. From May to September 2011, a semi-structured questionnaire survey had been conducted. A total of 135 respondents had been surveyed.

Table 1. Critical indicators and questions on the multi-impacts.

\begin{tabular}{|c|c|c|}
\hline & Critical indicators & Generated questions \\
\hline \multirow{3}{*}{ Social impact } & & $\begin{array}{l}\text { Q.1. How do you describe your familiarity or connection with the } \\
\text { revitalization project? }\end{array}$ \\
\hline & - Linkage between community and project; & $\begin{array}{l}\text { Q.2. How much does the historic building help enhance community } \\
\text { identity of the local Sham Shui Po district? }\end{array}$ \\
\hline & & $\begin{array}{l}\text { Q.3. How would you evaluate the creation of collective memory or } \\
\text { community cohesion after the completion of the project? }\end{array}$ \\
\hline \multirow{3}{*}{$\begin{array}{l}\text { Cultural } \\
\text { impact }\end{array}$} & \multirow{3}{*}{$\begin{array}{l}\text { - Conservation of historic built environment; } \\
\text { - Historic building as cultural landmarks; } \\
\text { - Linkage between historic building and end-uses. }\end{array}$} & $\begin{array}{l}\text { Q.4. How would you evaluate the cultural and historic built environment } \\
\text { after the completion of the project? }\end{array}$ \\
\hline & & Q.5. Is the heritage of this historic building preserved after renovation? \\
\hline & & $\begin{array}{l}\text { Q.6. How much does this historic building contribute to the local overall } \\
\text { cultural environment? }\end{array}$ \\
\hline \multirow{3}{*}{$\begin{array}{l}\text { Economical } \\
\text { impact }\end{array}$} & \multirow{3}{*}{$\begin{array}{l}\text { - Creating job opportunities throughout the project; } \\
\text { - Economic development of social enterprises; } \\
\text { - Tourism potentials or businesses related with } \\
\text { cultural heritage environment; } \\
\text { - Broader economic issues, e.g. agglomeration of } \\
\text { similar industries. }\end{array}$} & $\begin{array}{l}\text { Q.7. How much does this revitalization project contribute to the economy } \\
\text { of local Sham Shui Po district? }\end{array}$ \\
\hline & & $\begin{array}{l}\text { Q.8. Would you visit this building together with the other two historic } \\
\text { buildings nearby, i.e. the Jockey Club Creative Arts Centre and Mei Ho } \\
\text { House? }\end{array}$ \\
\hline & & $\begin{array}{l}\text { Q.9. How much would you score the overall success of this revitalization } \\
\text { project? }\end{array}$ \\
\hline
\end{tabular}


Table 2. Connections between the key stakeholders and the NKM project.

\begin{tabular}{rlll}
\hline \multicolumn{1}{l}{ Key stakeholders } & Connections with the NKM project & Persons \\
\hline 1 & Contractor workers & May directly influence the NKM revitalization project process and its result. \\
2 & End-users (SCAD HK) & $\begin{array}{l}\text { Could benefit directly from the revitalization project. } \\
\text { Their lives could be affected to varying degrees as many SCAD staff members and students are } \\
\text { expected to visit local restaurants and stay in local rental houses. }\end{array}$ & 15 \\
3 & Local residents & $\begin{array}{l}\text { As an art college, the end-user of the NKM building (SCAD) offers courses similar to those of the } \\
\text { design school of the local nearby university. The staff members and students from art- and } \\
\text { design-related departments in the local university might be affected by the outcome of the } \\
\text { revitalization project. }\end{array}$ & $\begin{array}{l}\text { Concerned group } \\
\text { members (Local nearby } \\
\text { university staff/students }\end{array}$ \\
Total & & & 65 \\
\hline
\end{tabular}

Aside from the questionnaire survey, two site visits to the NKM building were organized by the research team, which were followed by focus group discussions to solicit the participants' views on the effectiveness and various impacts of the project. The focus group discussions would enhance the comprehension of the findings from the previous questionnaire survey. A total of 109 participants had been invited to join a guided tour to the NKM building. Each tour lasted approximately 45 minutes, and it was guided by the SCAD HK admissions staff.

\subsection{Data Analysis}

In the questionnaire survey, all the respondents were requested to rate their degree of agreement with each question in a five-point Likert scale, where 1 means "totally disagree" and 5 means "totally agree." The respondents' levels of involvement in the NKM project were also reported in the five-point Likert scale. In data analysis, the mean scores of each question and various impact of the project were analyzed through multiple regression (MR) and correlation analysis to examine the relationships among the variables. In MR, both enter and stepwise methods were applied.

By definition, the MR uses the independent variables whose values are known to predict the single dependent value, and correlation analysis measures the association between quantitative variables without distinction between the independent and dependent variables [33]. These methods could meet the research objective to explore the relationship between various factors and the multi-perspective impacts of the revitalization project. In the study, SPSS software was utilized to conduct the corresponding analysis. Various impacts of the NKM project (i.e., social, cultural, economical, as well as overall impacts) were selected as dependent variable. Six variables were considered as independent variables, namely, gender, age, education, project involvement, employment, and income.

\subsubsection{Social Impact as Dependent Variable}

First, social impact was selected as the dependent variable. Through enter method, the regression result as expressed in Table 3 showed that, compared with other factors, the interviewee's involvement in the project had a positive 
Table 3. Regression coefficient (social impact as dependent variable in enter method).

\begin{tabular}{|c|c|c|c|c|c|c|}
\hline & \multirow[t]{2}{*}{ Model } & \multicolumn{2}{|c|}{$\begin{array}{l}\text { Unstandardized } \\
\text { coefficient }\end{array}$} & \multirow{2}{*}{$\begin{array}{c}\begin{array}{c}\text { Standardized } \\
\text { coefficient }\end{array} \\
\text { Beta }\end{array}$} & \multirow[t]{2}{*}{$\mathrm{t}$} & \multirow{2}{*}{ Sig. } \\
\hline & & B & Std. Error & & & \\
\hline \multirow{7}{*}{1} & (Constants) & 2.709 & 0.469 & & 5.770 & 0.000 \\
\hline & GENDER & -0.133 & 0.103 & -0.089 & -1.302 & 0.197 \\
\hline & AGE & -0.050 & 0.110 & -0.037 & -0.457 & 0.649 \\
\hline & EDUCATION & -0.178 & 0.110 & -0.135 & -1.618 & 0.109 \\
\hline & INVOLVEMENT & 0.370 & 0.049 & 0.707 & 7.625 & 0.000 \\
\hline & EMPLOYMENT & 0.058 & 0.074 & 0.079 & 0.777 & 0.439 \\
\hline & INCOME & 0.079 & 0.058 & 0.104 & 1.357 & 0.178 \\
\hline
\end{tabular}

a. Predictors: (Constants), GENDER, AGE, EDUCATION, INVOLVEMENT, EMPLOYMENT, INCOME. b. Dependent variable: SOCIAL IMPACT.

and significant influence on the project's social impact at the significance level of 0.00. This finding was also observed through the stepwise regression analysis. In the stepwise regression result, the other independent variables except the level of involvement, such as gender, age, education, employment, and income, were automatically removed from the equation because of their low statistical contribution to social impact.

\subsubsection{Cultural Impact as Dependent Variable}

Second, cultural impact was selected as the dependent variable. Through enter method, the regression result as expressed in Table 4 showed that, compared with other factors, the interviewee's gender and education level negatively contributed to the project's cultural impact, while their involvement in the project had a positive influence on the project's cultural impact. This finding was also observed through the stepwise regression analysis. In the stepwise regression result, the independent variables, such as age, employment, and income, were automatically removed from the equation because of their low statistical contribution to cultural impact.

\subsubsection{Economical Impact as Dependent Variable}

Third, economical impact was selected as the dependent variable. Through enter method, the regression result as expressed in Table 5 showed that, compared with other factors, the interviewee's education level negatively contributed to the project's perceptual economical impact, while their involvement in the project had a positive and significant influence on the project's economical impact. Both factors were at the significance level of 0.00 . This finding was also observed through the stepwise regression analysis. In the stepwise regression result, the independent variables, such as gender, age, employment, and income, were automatically removed from the equation because of their low statistical contribution to economical impact. 
Table 4. Regression coefficient (cultural impact as dependent variable in enter method).

\begin{tabular}{|c|c|c|c|c|c|c|}
\hline & \multirow[t]{2}{*}{ Model } & \multicolumn{2}{|c|}{$\begin{array}{l}\text { Unstandardized } \\
\text { coefficient }\end{array}$} & \multirow{2}{*}{$\begin{array}{c}\text { Standardized } \\
\text { coefficient }\end{array}$} & \multirow[t]{2}{*}{$\mathrm{t}$} & \multirow[t]{2}{*}{ Sig. } \\
\hline & & B & Std. Error & & & \\
\hline \multirow{7}{*}{1} & (Constants) & 4.945 & 0.612 & & 8.086 & 0.000 \\
\hline & GENDER & -0.274 & 0.134 & -0.195 & -2.055 & 0.043 \\
\hline & AGE & 0.010 & 0.144 & 0.008 & 0.068 & 0.946 \\
\hline & EDUCATION & -0.598 & 0.143 & -0.484 & -4.172 & 0.000 \\
\hline & INVOLVEMENT & 0.149 & 0.063 & 0.304 & 2.356 & 0.021 \\
\hline & EMPLOYMENT & 0.003 & 0.097 & 0.004 & 0.030 & 0.976 \\
\hline & INCOME & 0.065 & 0.076 & 0.091 & 0.854 & 0.396 \\
\hline
\end{tabular}

a. Predictors: (Constants), GENDER, AGE, EDUCATION, INVOLVEMENT, EMPLOYMENT, INCOME. b. Dependent variable: CULTURAL IMPACT.

Table 5. Regression coefficient (economical impact as dependent variable in enter method).

\begin{tabular}{|c|c|c|c|c|c|c|}
\hline & \multirow[t]{2}{*}{ Model } & \multicolumn{2}{|c|}{$\begin{array}{l}\text { Unstandardized } \\
\text { coefficient }\end{array}$} & \multirow{2}{*}{$\begin{array}{c}\begin{array}{c}\text { Standardized } \\
\text { coefficient }\end{array} \\
\text { Beta }\end{array}$} & \multirow[t]{2}{*}{$\mathrm{t}$} & \multirow[t]{2}{*}{ Sig. } \\
\hline & & B & Std. Error & & & \\
\hline \multirow{7}{*}{1} & (Constants) & 4.754 & 0.713 & & 6.667 & 0.000 \\
\hline & GENDER & -0.189 & 0.156 & -0.113 & -1.212 & 0.229 \\
\hline & AGE & 0.055 & 0.167 & 0.037 & 0.330 & 0.742 \\
\hline & EDUCATION & -0.700 & 0.167 & -0.479 & -4.192 & 0.000 \\
\hline & INVOLVEMENT & 0.227 & 0.074 & 0.393 & 3.085 & 0.003 \\
\hline & EMPLOYMENT & -0.061 & 0.113 & -0.075 & -0.542 & 0.589 \\
\hline & INCOME & 0.100 & 0.089 & 0.119 & 1.131 & 0.261 \\
\hline
\end{tabular}

a. Predictors: (Constants), GENDER, AGE, EDUCATION, INVOLVEMENT, EMPLOYMENT, INCOME. b. Dependent variable: ECONOMICAL IMPACT.

\subsubsection{Overall Impact as Dependent Variable}

At last, the overall impact, including social impact, cultural impact, and economical impact, was selected as the dependent variable. Through the enter method, the regression result as expressed in Table 6 resembled the features when economical impact was set as the dependent variable. The interviewee's education level negatively contributed to the project's overall impact, while their involvement in the project had a positive and significant influence on the overall impact. Both factors were at the significance level of 0.00 . This finding was also observed through the stepwise regression analysis. In the stepwise regression result, the independent variables, such as gender, age, employment, and income, were automatically removed from the equation because of their low statistical contribution to overall impact.

The MR results demonstrated that the level of the interviewee's involvement with the project and education level were the two most significant factors on the 
Table 6. Regression coefficient (overall impact as dependent variable in enter method).

\begin{tabular}{ccccccc}
\hline \multirow{2}{*}{ Model } & \multicolumn{2}{c}{$\begin{array}{c}\text { Unstandardized } \\
\text { coefficient }\end{array}$} & $\begin{array}{c}\text { Standardized } \\
\text { coefficient }\end{array}$ & $\mathrm{t}$ & Sig. \\
\cline { 2 - 4 } & B & Std. Error & Beta & & \\
\hline (Constants) & 3.894 & 0.472 & & 8.247 & 0.000 \\
GENDER & -0.194 & 0.103 & -0.146 & -1.882 & 0.063 \\
AGE & -0.004 & 0.111 & -0.003 & -0.037 & 0.971 \\
& EDUCATION & -0.426 & 0.111 & -0.365 & -3.850 & 0.000 \\
& 0.264 & 0.049 & 0.572 & 5.415 & 0.000 \\
& INVOLVEMENT & 0.014 & 0.075 & 0.022 & 0.190 & 0.850 \\
EMPLOYMENT & 0.075 & 0.059 & 0.112 & 1.285 & 0.202 \\
\hline
\end{tabular}

a. Predictors: (Constants), GENDER, AGE, EDUCATION, INVOLVEMENT, EMPLOYMENT, INCOME. b. Dependent variable: OVERALL IMPACT.

project's various impacts. The level of involvement with the project positively and significantly contributed to the project's impacts. At the same time, the interviewee's education level was negatively associated with the project's cultural, economic, and overall impacts.

To examine the relationships among the various impacts and the two most significant factors, this research carried out correlation analysis (Table 7). The relationship between any two variables was expressed through correlation coefficient, which was represented by a value within the range from -1.00 to +1.00 . A correlation coefficient $>0.00$ implied a positive correlation between the two variables. A correlation coefficient equaling 0 implied no correlation. A correlation coefficient $<0.00$ implied a negative correlation between the two variables.

\section{Discussion}

\subsection{Correlation of Respondents' Views on the Project's Various Impacts}

The correlation analysis result (Table 7) indicated no negative correlation between any two impacts. In the respondents' perspectives, the development of social and cultural aspects did not conflict with the economic development of the revitalization project. The economic impact, which was expressed from Q7 to Q9, was significantly and positively correlated with the cultural impact, which was expressed from Q4 to Q6. In addition, the economic concerns in Q7 and Q9 were positively correlated with both the social and cultural impacts, which were expressed from Q1 to Q6, at the significance level of 0.00 . These phenomena implied that concerns on social development and heritage conservation could significantly contribute to the economic development of the NKM project. The revitalization project of the NKM building through conservation and adaptive reuse could achieve its initial objective, that is, to maximize the economic and socio-cultural benefits of the building. This finding coincided with the findings from the mean score analysis and focus group discussions. 
Table 7. Correlation analysis among various impacts and two significant factors.

\begin{tabular}{|c|c|c|c|c|c|c|c|c|c|c|c|c|}
\hline & & Q.1 & Q.2 & Q.3 & Q.4 & Q.5 & Q.6 & Q.7 & Q.8 & Q.9 & Edu. & Inv. \\
\hline \multirow{3}{*}{ Q.1 } & P. Corr. & 1 & & & & & & & & & & \\
\hline & Sig. (2-tailed) & & & & & & & & & & & \\
\hline & $\mathrm{N}$ & 135 & & & & & & & & & & \\
\hline \multirow{3}{*}{ Q.2 } & P. Corr. & $0.312^{\star *}$ & 1 & & & & & & & & & \\
\hline & Sig. (2-tailed) & 0.001 & & & & & & & & & & \\
\hline & $\mathrm{N}$ & 135 & 135 & & & & & & & & & \\
\hline \multirow{3}{*}{ Q.3 } & P. Corr. & $0.226^{*}$ & $0.483^{\star *}$ & 1 & & & & & & & & \\
\hline & Sig. (2-tailed) & 0.018 & 0.000 & & & & & & & & & \\
\hline & $\mathrm{N}$ & 135 & 135 & 135 & & & & & & & & \\
\hline \multirow{3}{*}{ Q.4 } & P. Corr. & $0.253^{\star \star}$ & $0.416^{\star *}$ & $0.442^{\star *}$ & 1 & & & & & & & \\
\hline & Sig. (2-tailed) & 0.008 & 0.000 & 0.000 & & & & & & & & \\
\hline & $\mathrm{N}$ & 135 & 135 & 135 & 135 & & & & & & & \\
\hline \multirow{3}{*}{ Q.5 } & P. Corr. & $0.457^{\star *}$ & $0.412^{* *}$ & 0.169 & $0.387^{* *}$ & 1 & & & & & & \\
\hline & Sig. (2-tailed) & 0.000 & 0.000 & 0.078 & 0.000 & & & & & & & \\
\hline & $\mathrm{N}$ & 135 & 135 & 135 & 135 & 135 & & & & & & \\
\hline \multirow{3}{*}{ Q.6 } & P. Corr. & $0.378^{\star \star}$ & $0.470^{\star \star}$ & $0.401^{* *}$ & $0.388^{\star *}$ & $0.461^{\star *}$ & 1 & & & & & \\
\hline & Sig. (2-tailed) & 0.000 & 0.000 & 0.000 & 0.000 & 0.000 & & & & & & \\
\hline & $\mathrm{N}$ & 135 & 135 & 135 & 135 & 135 & 135 & & & & & \\
\hline \multirow{3}{*}{ Q.7 } & P. Corr. & $0.382^{\star \star}$ & $0.534^{\star *}$ & $0.375^{\star *}$ & $0.375^{\star \star}$ & $0.425^{\star *}$ & $0.639^{* *}$ & 1 & & & & \\
\hline & Sig. (2-tailed) & 0.000 & 0.000 & 0.000 & 0.000 & 0.000 & 0.000 & & & & & \\
\hline & $\mathrm{N}$ & 135 & 135 & 135 & 135 & 135 & 135 & 135 & & & & \\
\hline \multirow{3}{*}{ Q.8 } & P. Corr. & 0.157 & $0.232^{*}$ & 0.129 & 0.151 & $0.334^{\star *}$ & $0.439^{* *}$ & $0.451^{\star *}$ & 1 & & & \\
\hline & Sig. (2-tailed) & 0.101 & 0.015 & 0.178 & 0.116 & 0.000 & 0.000 & 0.000 & & & & \\
\hline & $\mathrm{N}$ & 135 & 135 & 135 & 135 & 135 & 135 & 135 & 135 & & & \\
\hline \multirow{3}{*}{ Q.9 } & P. Corr. & $0.393^{* *}$ & $0.537^{\star *}$ & $0.461^{\star *}$ & $0.532^{* *}$ & $0.613^{* *}$ & $0.598^{\star *}$ & $0.511^{\star \star}$ & $0.345^{\star *}$ & 1 & & \\
\hline & Sig. (2-tailed) & 0.000 & 0.000 & 0.000 & 0.000 & 0.000 & 0.000 & 0.000 & 0.000 & & & \\
\hline & $\mathrm{N}$ & 135 & 135 & 135 & 135 & 135 & 135 & 135 & 135 & 135 & & \\
\hline \multirow{3}{*}{ Edu. } & P. Corr. & -0.074 & $-0.331^{\star \star}$ & -0.133 & 0.000 & -0.021 & -0.109 & $-0.346^{\star *}$ & -0.142 & -0.164 & 1 & \\
\hline & Sig. (2-tailed) & 0.445 & 0.000 & 0.167 & 1.000 & 0.824 & 0.257 & 0.000 & 0.139 & 0.087 & & \\
\hline & $\mathrm{N}$ & 135 & 135 & 135 & 135 & 135 & 135 & 135 & 135 & 135 & 135 & \\
\hline \multirow{3}{*}{ Inv. } & P. Corr. & $0.866^{\star *}$ & $0.302^{\star *}$ & $0.256^{\star *}$ & $0.207^{*}$ & $0.439^{\star *}$ & $0.420^{\star *}$ & $0.369^{* *}$ & $0.229^{*}$ & $0.376^{* *}$ & -0.074 & 1 \\
\hline & Sig. (2-tailed) & 0.000 & 0.001 & 0.007 & 0.030 & 0.000 & 0.000 & 0.000 & 0.016 & 0.000 & 0.442 & \\
\hline & $\mathrm{N}$ & 135 & 135 & 135 & 135 & 135 & 135 & 135 & 135 & 135 & 135 & 135 \\
\hline
\end{tabular}

**. Correlation is significant at the 0.01 level (2-tailed). ${ }^{*}$. Correlation is significant at the 0.05 level (2-tailed). 
The mean score analysis revealed that the 135 respondents expressed a rather positive evaluation of the project's overall impact with a mean score of 3.4 out of the five-point Likert scale [34]. This positive evaluation was also observed in the focus group discussions. The majority of group members responded positively, agreeing that the NKM project was well conserved and re-used. Some respondents supported that the project was successful in terms of the conservation and adaptive re-use of the building structure. Other respondents added that the original NKM building was well suited for the new purpose, although certain drawbacks remained, such as the small library and high tuition fees at SCAD $\mathrm{HK}^{1}$. The high tuition fee made enrollment in SCAD HK difficult for ordinary local students. Some respondents also pointed out that walk-in visitation would be impossible without a complex registration process. To a certain extent, this shortcoming limited the interactions between the revitalization project and the local community [16]. Although most respondents highly praised the success of the revitalization project, they pointed out issues that thwarted the close interactions between the local community and the building both before and after revitalization.

\subsection{Positive Correlation between Involvement Level and Various Impacts}

The results of MR analysis indicated a positive correlation between the level of involvement and various impacts, which were expressed from Q1 to Q9, at the significance level of 0.00 . The questionnaire survey revealed that the respondents with higher levels of involvement with the project tended to evaluate the project more favorably. For instance, the contractor workers from Hsin Chong, a construction company, who had been heavily involved with the project, expressed a very positive and high evaluation of the project's impacts. The same is noted with SCAD staff/students, as the end-users of the building. This finding had also been attested by the mean score analysis. The overall mean score by contractor workers was 4 .1out of the five-point Likert scale, and the mean score by SCAD staff/students was 4.0. By contrast, the respondents with lower levels of involvement with the project expressed less favorable evaluations. For instance, the local Sham Shui Po residents had very limited connections with the NKM building either before or after revitalization, and their evaluations of the project's impacts were relatively lower with a mean score of 2.9 [34].

The local community's low level of involvement had been complained by many respondents during the group discussions. Some respondents pointed out that local residents would not visit the former NKM building voluntarily, as the Chinese saying claimed, "you would never go to court when you are alive just as you would never go to hell when you die" [16]. In addition, the revitalized usage as an arts college was also unfamiliar to the local residents. These particular

${ }^{1}$ The tuition fee of SCAD HK in 2011 was over HK\$200,000 per year, while the average annual income in the same year in Hong Kong was only HK\$155,724

(http://www.yearbook.gov.hk/2011/en/pdf/Facts.pdf). 
functions with the building, either before or after revitalization, did not contribute to the development of close connections between the local people and the building. At the same time, many participants believed that the remote location of the building on the outskirts of the old town area doomed it from establishing close connections with the local residents. Furthermore, considering the limited government publicity about the project, few local people actually knew about this project until recently.

To enhance the connections between the local people and the historic building, many participants suggested that they preferred if the building could serve the Hong Kong community, such as a shopping mall or even a museum, rather than the current arts college. The college could draw few local residents because of the high tuition fees and high-level image. Some respondents commented that the earlier controversial opinions regarding the building's end use as a Cantonese opera house would probably serve the Hong Kong community better than its current use [16]. From these discussions, the connections between the local people and the end use of the building substantially influenced the respondents' evaluations of the local government's earlier decisions concerning the revitalization project.

\subsection{Negative Correlation between Education Level and Various Impacts}

The study found that, compared with other factors, education had the second strongest relationship with cultural, economical, and overall impacts. Contrary to the positive relationship between the level of involvement and various impacts, education level tended to be negatively associated with the community's evaluations of the corresponding impacts. The result of correlation analysis revealed that education level was significantly associated with Q2 and Q7. Q2 (How much does the historic building help enhance community identity of the local Sham Shui Po district?) explored the contribution of the historic building to the development of community identity, including either emotional belonging or actual inter-relationships [35]. This question investigated the extent to which the building affected the social lives of the respondents or the relationships that might exist between the respondents and the building. In this research, the respondents with higher education levels were mainly staff/students from SCAD and the nearby local university. Normally, the respondents with higher education levels were likely to be more critical and tended to have higher expectations on the revitalization project. Accordingly, their evaluations of the project's contribution to the development of community identity would be less favorable. Nevertheless, respondents with similar education levels but higher levels of involvement with the project expressed more favorable opinions than those with lower levels of involvement. For instance, the mean score of the SCAD staff/students' evaluations of the project's outcome (4.0 out of the five-point Likert scale) was significantly higher than that of nearby local university 
staff/students (3.3 out of the five-point Likert scale). Compared with nearby local university staff/students, local residents expressed even less favorable opinions on the project's impacts (with a mean score of 2.9) [34]. This situation might be due to the local residents' significant lack of connection with the NKM project.

Q7 (How much does this revitalization project contribute to the economy of local Sham Shui Po district?) explored the potential economic contribution of the project toward the local community. The respondents with higher education levels (e.g., nearby local university staff/students) were greatly concerned about the financial situations of the SCAD HK. The high tuition fees undermined the enrollment rate of SCAD HK. Considering the high tuition fees and low student enrollment, some respondents expressed their concerns over the financial sustainability of SCAD HK in the long run [16]. Accordingly, these respondents expressed comparatively less favorable opinions. In the focus group discussions, many respondents commented that such economical concerns over the financial capability of the end-user also reminded people of the criteria that the Hong Kong government set to select the most qualified service provider for the project [17]. In contrast with the aforementioned concerns, many local residents with relatively lower education levels expressed more expectations from SCAD staff/students' daily consumption in the old town area. For instance, SCAD staff/students were expected to visit restaurants or stay in rental houses operated by local residents [34]. Accordingly, the local residents tended to evaluate the project's potential economic contributions rather positively.

\section{Conclusions}

This study explored how community involvement influenced the community's evaluation of the revitalization projects in Hong Kong. Based on the case study on the NKM project, the research demonstrated the significant role of community connections with the revitalization project in the community's favorable evaluations of the project's various impacts, including social, cultural, and economical impacts. Generally, when the local community had higher levels of involvement with the project, the members tended to evaluate the project more favorably. Inversely, the community's evaluations were less favorable with lower levels of participation. Given the limited government publicity about the NKM project, the local community had minimal knowledge about the project, which seriously undermined the community's understanding of the government's decisions on the project and the community's evaluations of the project.

In addition to the level of involvement, the paper identified education level as the second most significant factor affecting the local community's evaluations of the project's impacts. In contrast with the level of involvement, education level tended to be negatively associated with the community's evaluations. Nonetheless, a careful examination revealed that the issue of connection or interactions between the project and the respondents with different education levels actually 
affected the respondents' opinions. At the same time, the result of correlation analysis of various perceptual impacts displayed that in the public's perspectives, the social development and cultural heritage conservation would significantly contribute to the economic development of the project. This implied that revitalization projects, through conservation and adaptive re-use of historic buildings, could achieve the initial development goals proposed by the Hong Kong government, that is, to maximize the economic and socio-cultural benefits of the building.

Based on these findings, strategies for improving Hong Kong society's opinions on the revitalization project should focus on the enhancement of the community's connection or interaction with the project. Many functions/activities should be organized to engage the local Sham Shui Po community with the NKM project. As noted from the interviews, the local residents suggested that they would know the NKM project better if SCAD HK could organize guided tours to their campus even over the weekends, provide free art exhibitions, or offer short-term arts and design courses at concessionary fees. Through these activities, the level of involvement of the local community with the NKM project would be enhanced, which would positively influence the local people's evaluation of the project's outcomes.

Nowadays, the public expresses increasing interest and enthusiasm in heritage conservation and revitalization projects. To foster better interactions between the society and other revitalized projects in Hong Kong, the Development Bureau of Hong Kong SAR should consider specifying certain "after-sales activities" that must be provided by the service providers such that the public could be better connected with the renovated historic buildings. The government should provide continuous efforts to publicize the revitalized projects to arouse the local community's interest. Additional efforts should be exerted to educate the public in appreciating the social and cultural heritage values of historic buildings.

\section{Acknowledgements}

This work was supported by the "National Natural Science Foundation of China" (No. 51578451); "Research Grants Council of the Hong Kong SAR China" (No. PolyU 5002-PPR-10); "Fundamental Research Funds for the Central Universities" (No. xjj2015040); and "Key Scientific Research Innovation Team Project of Shaanxi Province" (No. 2016KCT-14). The authors also wish to thank other team members including Dr. Esther Cheung, Dr. Kim-Wah Chung, Dr. Chi-Pang Lau, Dr. Jingfeng Yuan, and Dr. Zhiru Wang.

\section{References}

[1] Lichfield, N. (1988) Economics in Urban Conservation. Cambridge University Press in Association with Jerusalem Institute for Israel Studies, Jerusalem, Cambridge.

[2] Tiesdell, S., Oc, T. and Heath, T. (1996) Revitalizing Historic Urban Quarters. Butterworth-Architecture, London.

[3] UNESCO (2008) Historic Districts for All: A Social and Human Approach for Sus- 
tainable Revitalization. http://unesdoc.unesco.org/images/0017/001784/178420e.pdf

[4] Harvey, D. (1985) The Urbanization of Capital: Studies in the History and Theory of Capitalist Urbanization. Blackwell, Oxford.

[5] Steinberg, F. (1996) Conservation and Rehabilitation of Urban Heritage in Developing Countries. Habitat International, 20, 463-475. https://doi.org/10.1016/0197-3975(96)00012-4

[6] Tiesdell, S. (1995) Tensions between Revitalization and Conservation: Nottingham's Lace Market. Cities, 12, 231-241. https://doi.org/10.1016/0264-2751(95)00040-S

[7] DB (Development Bureau) (2009a) Creative Proposals Selected to Revitalise Historic Buildings.

http://www.devb.gov.hk/en/publications_and_press_releases/press/index_id_4692.h $\underline{\mathrm{tml}}$

[8] DB (Development Bureau) (2009b) Legislative Council Panel on Development Revitalising Historic Buildings through Partnership Scheme.

http://www.devb.gov.hk/filemanager/article/en/upload/5594/LegCo\%20Panel\%20P aper\%2024\%20Feb\%202009\%20eng.pdf

[9] STD (Sing Tao Daily) (2009) Chinese Artists Association Should Let Public Judge Its Proposal. Sing Tao Daily.

[10] Campbell, H. and Marshall, R. (2000) Public Involvement and Planning: Looking beyond the One to the Many. International Planning Studies, 5, 321-344. https://doi.org/10.1080/713672862

[11] Reid, J.N. (2000) Community Participation-How People Power Brings Sustainable Benefits to Communities. http://www.rurdev.usda.gov/rbs/ezec/Pubs/commparticrept.pdf

[12] Carter, A. (2000) Strategy and Partnership in Urban Regeneration. In: Roberts, P.W. and Sykes, H., Eds., Urban Regeneration: A Handbook, SAGE Publications, London, 37-58.

[13] Roberts, P. (2000) Evolution, Definition and Purpose of Urban Regeneration. In: Roberts, P.W. and Sykes, H., Eds., Urban Regeneration: $A$ Handbook, SAGE Publications, London, 9-36.

[14] Yung, E.H.K. and Chan, E.H.W. (2011) Problem Issues of Public Participation in Built-Heritage Conservation: Two Controversial Cases in Hong Kong. Habitat International, 35, 457-466. https://doi.org/10.1016/j.habitatint.2010.12.004

[15] DB (Development Bureau) (2007a) Legislative Council Panel on Home Affairs-Revitalizing Historic Buildings through Partnership Scheme.

http://www.heritage.gov.hk/en/doc/HA\%20Panel\%20-\%20RHBTP\%20Scheme\%20( Eng).pdf

[16] Cheung, E. and Chan, A.P.C. (2014) Revitalizing Historic Buildings through a Partnership Scheme: Innovative Form of Social Public-Private Partnership. Journal of Urban Planning and Development, 140, 1-9. https://doi.org/10.1061/(ASCE)UP.1943-5444.0000161

[17] DB (Development Bureau) (2007) Legislative Council Brief-Heritage Conservation Policy. http://www.heritage.gov.hk/en/doc/LC_Brief_Heritage_Conservation.pdf

[18] Arnstein, S.R. (1969) Ladder of Citizen Participation. Journal of the American Institute of Planners, 35, 216-224. https://doi.org/10.1080/01944366908977225

[19] Paul, S. (1987) Community Participation in Development Projects: The World Bank Experience. Readings in Community Participation. http://documents.worldbank.org/curated/en/home 
[20] Chan, K.W. and Yeung, C.W. (2008) Assessing Citizen Perceptions on Community Participations and Social Bonding-The Case of Urban Renewal in Hong Kong. International Research Symposium on Advancement of Construction Management and Real Estate, Beijing, 31 October-3 November 2008, 525-535.

[21] Dassopoulos, A. and Monnat, S.M. (2010) Do Perceptions of Social Cohesion, Social Support, and Social Control Mediate the Effects of Local Community Participation on Neighborhood Satisfaction? Environment and Behavior, 43, 546-565.

[22] Leigh, J.R. (1989) Citizen Participation in Frisco Main Street: Revitalization. Landscape and Urban Planning, 17, 297-304. https://doi.org/10.1016/0169-2046(89)90083-2

[23] Cheng, J.Y.S. (1999) Political Participation in Hong Kong: Theoretical Issues and Historical Legacy. City University of Hong Kong Press, Hong Kong.

[24] Cook, A.H.S. and Ng, M.K. (2000) Sustainable Communities: Discovering Community Perspectives in Planning Hong Kong. Planning and Development, 16, 3-11.

[25] Cheng, J.Y.S. (2014) New Trends of Political Participation in Hong Kong. City University of Hong Kong Press, Hong Kong.

[26] AMO (Antiquities and Monuments Office) (2012) Introduction to 1444 Historic Buildings. http://www.amo.gov.hk/en/download.php

[27] Becker, H.A. (2001) Social Impact Assessment. European Journal of Operational Research, 128, 311-321. https://doi.org/10.1016/S0377-2217(00)00074-6

[28] Mathur, H.M. (2011) Social Impact Assessment: A Tool for Planning Better Resettlement. Social Change, 41, 97-120. https://doi.org/10.1177/004908571104100105

[29] Vanclay, F. (2003) International Principles for Social Impact Assessment. Impact Assessment \& Project Appraisal, 21, 5-11.

https://doi.org/10.3152/147154603781766491

[30] Hou, J. (2005) America's New Downtowns: Revitalization or Reinvention? Landscape and Urban Planning, 73, 74-75. https://doi.org/10.1016/j.landurbplan.2005.01.001

[31] Mason, R. (2008) Be Interested and Beware: Joining Economic Valuation and Heritage Conservation. International Journal of Heritage Studies, 14, 303-318. https://doi.org/10.1080/13527250802155810

[32] Li, T.H.Y., Ng, S.T. and Skitmore, M. (2012) Conflict or Consensus: An Investigation of Stakeholder Concerns during the Participation Process of Major Infrastructure and Construction Projects in Hong Kong. Habitat International, 36, 333-342. https://doi.org/10.1016/j.habitatint.2011.10.012

[33] Hair-Jr., J.F., Black, W.C., Babin, B.J. and Anderson, R.E. (2009) Multivariate Data Analysis. 7th Edition, Pearson, Upper Saddle River.

[34] Zhai, B. and Chan, A.P.C. (2015) Community Participation and Community Evaluation of Heritage Revitalisation Projects in Hong Kong. Open House International, 40, 54-61.

[35] Wilson, G.D. (2010) Community, Identity, and Social Memory at Moundville. American Antiquity, 75, 3-18. https://doi.org/10.7183/0002-7316.75.1.3 